Sitasi artikel ini (APA $6^{\text {th }}$ Edition style):

Tanjung, Y. (2018). Jejak Islam di Kota Binjai, Sumatera Utara. MUKADIMAH 2(1), 73-83.

\title{
Jejak Islam di Kota Binjai, Sumatera Utara
}

\author{
Yushar Tanjung \\ Jurusan Pendidikan Sejarah, Fakultas Ilmu Sosial, Universitas Negeri Medan, \\ Medan \\ yushartanjung88@gmail.com
}

\begin{abstract}
ABSTRAK
Kajian ini difokuskan pada proses awal masuknya agama Islam di Kota Binjai dan proses perkembangannya. Untuk mengetahui tokoh-tokoh yang berpengaruh dalam perkembangan agama Islam di Kota Binjai, untuk mengetahui bangunan-bangunan peninggalan komunitas Islam Binjai dan untuk mengetahui peninggalan Islam yang masih terdapat sekarang. Pembahasan ini dilaksanakan dengan pendekatan historis dengan menggunakan metode Library Research (metode penelitian kepustakaan) dan Field Research (metode penelitian lapangan) dengan melakukan wawancara selain pengumpulan data secara telaah pustaka Teknik pengumpulan data yang dilakukan dengan mengumpulkan dokumentasi terhadap peninggalan-peninggalan jejak Islam di Kota Binjai. Hasil yang diperoleh dari penelitian penyebaran Islam di Kota Binjai ini tidak terlepas dari peran yang besar dalam penyebaran agama Islam dari Kesultanan Langkat yang berkedudukan di Kota Binjai karena Binjai merupakan bagian dari kesultanan Langkat sebelum akhirnya membentuk daerahnya sendiri. Bahwa peran para tokoh sangat tinggi dalam proses Islamisasi melalui lembaga pendidikan yang dibuktikan derngan peninggalan Islam di Kota Binjai berupa masjid, makam, sekolah Islam dan karya para ulama.
\end{abstract}

Kata kunci: Islamisasi, tokoh ulama, Kota Binjai.

\section{PENDAHULUAN}

Penyebaran Islam yang terjadi di Asia Tenggara menghasilkan terjadinya akulturasi dan asimilasi budaya lokal sehingga membuahkan budaya baru yang dinamis dan unik. Catatan mengenai kerajaan besar Islam seperti Perlak di mana proses Islamisasinya dipengaruhi oleh para pedagang muslim juga menjadikan salah satu bukti penting dalam mengkaji proses masuknya agama Islam di Nusantara. Proses masuknya agama Islam di Indonesia menjadi kajian yang sangat menarik, karena terkait berbagai aspek yang meliputi perkembangan agama Islam di Indonesia itu sendiri. Pada akhir abad ke-13 dan abad ke-14 Islam telah membangun komunitas-komunitas niaga yang lebih jelas di kota-kota pelabuhan di Sumatera Utara, Jawa Timur, Campa, dan Pantai Timur Malaya. Penyebaran Islam juga tidak lepas dari orang-orang Asia Tenggara yang pernah ke Mekkah, seperti Sunan Gunung Jati (pendiri Banten- 
Islam), dan para sufi seperti Hamzah Fansuri, Abdurra'uf as-singkili, dan Syekh Yusuf.

Ketika Islam datang, masyarakat Indonesia telah berada dalam pengaruh Hindu-Buddha yang masing-masing penganutnya hidup berdampingan dalam damai. Kedatangan kaum muslim yang relatif damai diterima oleh sebagian masyarakat pribumi Indonesia yang membangun komunikasi dan interaksi dengan mereka terutama kaum bangsawan dan pedagang. Melalui pendekatan budaya, yang terjalin dalam hubungan perdagangan dengan para pendatang Islam dan bermukim menetap di kotakota dagang serta menikah dengan wanita pribumi telah membentuk komunitas sosial yang baru. Pengenalan Islam sebagai agama pendatang kepada masyarakat Indonesia penganut Hindu-Buddha, berproses secara damai. Dengan masuknya agama Islam ke Indonesia, secara empirik membawa kebudayaan Islam itu sendiri yang berpengaruh pula terhadap kehidupan masyarakat pribumi Indonesia. Islam ikut mewarnai kehidupan tradisi-tradisi yang ada di Indonesia. Sebab segala aktivitas kehidupan masyarakat yang menganut agama Islam, bersumber pada ajaran agama Islam.

Manakala Portugis pertama kali muncul di Asia, sesungguhnya masyarakat Asia Tenggara hidup dalam tataran toleransi tinggi sehingga mudah menerima dan menyerap pengaruh-pengaruh baru, seperti halnya mereka toleran terhadap agama Hindu, agama Buddha, dan agama Islam. Akan tetapi manakala Portugis mengganggu jaringan perdaganagan yang telah terjalin berabad-abad lama menimbulkan reaksi yang cukup signifikan dalam pengembangan Islam di Asia Tenggara. Diserangnya jaringan perdagangan ini secara implisit menumbuhkembangkan kebersamaan masyarakat Islam. Kerajaan Aceh Darussalam menjadi pionir dalam menghadapi gerak laju ekonomi dan sistem perdagangan yang digagas Portugis. Langkah yang ditempuh adalah membuka jaringan baru dan membangun bandar-bandar perdagangan tempat berintegrasi pedagang Islam yang tidak menerima sistem perdagangan yang diprakarsai Portugis. Munculnya pusat interaksi perdagangan yang baru ini telah membawa konsekuensi yang lebih jauh dalam pengembangan Islam di Asia Tenggara. Bahwa Portugis mempunyai andil dalam menyebarnya Islam di Asia Tenggara dapat dirunut dari proses ini. Kemakmuran sejumlah kerajaan penting, terutama Aceh dan Banten, bermula dari proses marginalisasi kaum Muslim oleh Portugis dalam aktivitas perdaganagn di Asia Tenggara.

Adapun yang menjadi rumusan masalah dalam tulisan ini proses awal Islam menapak di Kota Binjai, bagaimana perkembangan Islam di Binjai, hal apa saja yang dapat diidentifikasi sebagai peninggalan Islam di Binjai, bagaimana peran para tokoh dalam Islamisasi dan apa peninggalannya. Tujuan kajian ini untuk membahas persoalan di atas yang kemudian dinarasikan setelah menempuh langkah heuristik, verifikatif, dan interpretatif. 


\section{HASIL DAN PEMBAHASAN}

Islam di Sumatera Utara telah ada pada abad pertama Hijrah atau abad ke-7 M yang dikuatkan dengan sebaran makam dan gaya batu nisan yang variatif di Barus. Sayangnya jejak Islam ini tidak kontinu sehingga sulit menarik hubungannnya dengan Islam yang ada di Barus belakangan ini terutama setelah munculnya Kerajaan Aceh Darussalam abad ke XVI Akibat dari ketidak konsistenan ini memunculkan hipotesis bahwa Islam masuk ke Sumatera Utara dan menyebar ke daerah-daerah lain melalui Aceh. Islam telah mewarnai seluruh aspek kehidupan masyarakat baik secara politik, ekonomi maupun sosial. Pengaruh Islam secara sosial budaya begitu kuat membawa perubahan yang sangat signifikan pada kebudayaan dan penghidupan sehingga meninggalkan pengaruh yang terus-menerus hidup di masyarakat. Kesan Islam sebagai peradaban dapat ditemukan di manapun Islam telah dijadikan panutan oleh masyarakatnya. Peninggalan Islam merupakan bukti nyata keberadaan Islam telah merasuk jauh dalam pikiran dan menjadi indikator tentang aktivitas masyarakat muslim. Jadi jejak Islam merupakan suatu hal yang alamiah dan layak untuk dikaji.

Keberadaan peninggalan Islam di Kota Binjai merupakan peninggalan budaya, yang fenomenal dari sudut pandang lokal untuk ditelaah sebagai wujud kontak budaya yang menampilkan proses enkulturasi berkesinambungan. Perwujudan yang dimaksud di atas masih perlu ditelisik secara akademis. Apalagi masih minimnya penulisan sejarah tentang peninggalan Islam di Kota Binjai. Binjai telah dijadikan bandar/pelabuhan dengan mengekspor hasil pertanian lada yang berasal dari perkebunan lada di sekitar Ketapangai (Pungai), Namo Sira-sira serta kampung-kampung di hulu Sungai Bingai.

Proses awal dan berkembangnya agama Islam di Kota Binjai merupakan salah satu bagian dari wilayah Kesultanan Langkat. Kesultanan Langkat merupakan wilayah yang telah mengenal agama Islam melalui penyebaran Islam oleh pemuka agama yang berasal dari Aceh dan Minangkabau yang masuk ke Sumatera Timur pada waktu itu. Sehingga pada saat Binjai mulai membentuk dan mengatur wilayahnya sendiri yang tertulis dalam UndangUndang No. 9 Tahun 1956 tentang pembentukan daerah-daerah otonom, masyarakat Binjai telah mengenal agama Islam.

Islam masuk ke wilayah Kesultanan Langkat tidak terlepas dari kerajaan Aru yang telah mengenal Islam sejak pertengahan abad ke-13. Akibat kekalahan Kerajaan Aru yang berperang dengan Kerajaan Aceh di bawah pimpinan Sultan Iskandar Muda sekitar abad ke-16 yang sedang melakukan perluasan hingga ke wilayah Sumatera Timur menyebabkan hancurnya kerajaan Aru, yang kemudian didirikanlah kerajaan baru di derah Hamparan Perak, yang merupakan awal mula didirikannya Kerajaan Langkat. Dengan begitu agama Islam telah ada di Sumatera Timur sejak akhir abad ke-13 dan menyebabkan banyak daerah di Sumatera Timur yang mulai menganut agama 
Islam di bawah Kerajaan Aru. Pada waktu itu termasuk Kesultanan Langkat juga merupakan wilayah Kerajaan Aru. Sehingga Binjai telah mengenal agama Islam sejak masih di bawah kekuasaan Kesultanan Langkat.

Dalam proses dan masuknya Islam di Kota Binjai tidak pernah tersentuh oleh pengaruh agama Hindu-Buddha sebelum agama Islam masuk. Agama Hindu-Budha masuk setelah agama Islam menjadi agama mayoritas masyarakat di Kota Binjai. Namun ada pula kepercayaan masyarakat Kota Binjai yang bersifat kepada animisme dan dinamisme. Agama Islam berkembang pesat di Kota Binjai karena tokoh ulama setempat giat melakukan dakwah dan didukung oleh Kesultanan Langkat yang memerintah Kota Binjai. Pada awalnya agama Islam berkembang pesat di Kota Binjai karena Kesultanan Langkat mendukung penuh misi penyebaran agama Islam. Di dalam melaksanakan pemerintahannya, Sultan Langkat berpegang teguh kepada ajaran Islam. Karena ajaran Islam tidak bertentangan dengan hakekat manusia. Kesultanan Langkat juga menetapkan syarat bagi siapa yang menetap dan menjadi masyarakat Kota Binjai terlebih dahulu untuk memeluk agama Islam. Kesultanan Langkat juga membuka luas lapangan pekerjaan, baik di bidang pertanian yang mencapai swasembada pangan maupun bidang perdagangan. Kota Binjai terkenal sebagai kota yang aman dan strategis untuk bidang perdagangan. Karena itulah banyak masyarakat luas yang menetap di Kota Binjai.

\section{Identifikasi Peninggalan Islam di kota Binjai}

\section{Masjid Raya Kota Binjai}

Masjid Raya Binjai didirikan pada tahun 1887 oleh Tengku Haji Musa al-Khalid al-Mahadiah Muazzam Shah (Tengku Ngah) bin Raja Ahmad, yang menjabat 1840-1893 periode (Sultan Langkat I). Masjid Raya Binjai merupakan kebanggaan masyarakat lokal Kota Binjai yang jelas tidak bisa lepas dari pengaruh Kesultanan Langkat pada waktu itu. Sebelum menjadi status kotamadya, Binjai adalah ibukota Langkat yang kemudian dipindahkan ke Stabat. Bukti-bukti menunjukkan bahwa masjid ini secara langsung berkaitan dengan Kesultanan Langkat. Masjid ini pada tahun 1887 dibangun oleh Sultan Langkat Musa HI. Namun masjid ini resmi dibuka (diresmikan) oleh T. Sultan Abdul Aziz Langkat II pada tahun 1890. Sejak diresmikan, masjid ini digunakan muslim di Kota Binjai untuk shalat wajib dan sukarela dan kegiatan keagamaan lainnya sampai sekarang. Masjid ini kemudian direnovasi pada tahun 1924 sehingga terlihat seperti sekarang. Dalam perkembangan selanjutnya, baik selama atau setelah Kesultanan Langkat II, masjid ini menjadi pusat berbagai kegiatan, apakah itu terkait dengan komunitas agama Islam, sosial dan budaya di kota Binjai. Hal ini dibuktikan dengan digelarnya MTQ (Musabaqah Tilawatil Qur'an) Sumatera Timur yang diprakarsai oleh Syaikh H. Abdul Halim Hasan di Binjai pada tahun 1951.

Masjid ini memiliki nilai-nilai dan sejarah perjuangan bangsa Indonesia, termasuk masjid tertua di Sumatera Utara (sekarang berusia 124 
tahun), yang sebelumnya bernama Masjid Jami' (kemudian berubah namanya menjadi Masjid Binjai). Pembangunan Masjid itu sendiri bukan tanpa hambatan. Pada masa Tuanku Haji Musa, pembangunan masjid belum selesai dan belum digunakan sebagai tempat ibadah. Kemudian setelah Tuanku Haji Musa meninggal, posisinya digantikan oleh putranya Sultan Tuanku Abdul Aziz bin Abdul Jalil Rahmat Shah Sultan Haji Musa (1893-1927). Masa Depan Masjid Raya Binjai dikonstruksi hingga selesai dan kemudian diresmikan penggunaannya sebagai tempat beribadah dan dakwah. Masjid ini digunakan untuk pertama kalinya Shalat Jum'at pada tahun 1890 oleh Tengku Abd. Aziz (Sultan Langkat II). Ia juga berperan dalam pembangunan berkelanjutan sejumlah Masjid yang telah dirintis oleh Sultan Langkat I, dengan mengumpulkan hasil gaji raja-raja dan datok-datok masingmasing daerah di Langkat. Sejak diresmikan, masjid ini mulai digunakan sebagai tempat ibadah dan masih menjadi salah satu yang terbesar dan Masjid tertua di kota Binjai. Awal berdirinya, peran Masjid Binjai ini dalam Islam mengalami perkembangan yang sangat signifikan. Namun, sebagai Masjid Kesultanan selalu diisi dengan kegiatan lain yang melibatkan pengajian dari bapak-bapak atau ibu-ibu dan remaja, masjid ini tidak memiliki kegiatan rutin seperti pengajian masjid lainnya. Hal ini karena Masjid Binjai terletak di pusat kota di Jalan Binjai yaitu KH. Wahid Hasyim. Pada 1922 didirikan Yayasan Pendidikan Islam Al-Ishlahiyah di samping masjid. Masjid ini adalah hadiah keluarga Sultan Langkat, yang sampai sekarang masih eksis sebagai proses pembelajaran di Langkat dan di Kota Binjai, bahkan sekarang berkembang pesat, terbukti dengan pembukaan Sekolah Tinggi Agama Al-Islahiyah (STAIS).

\section{Masjid Jami' Limau Sunde}

Masjid Jami' dibangun pada tahun 1889 yang sekarang terletak di kelurahan Limau Sunde, Kecamatan Binjai Barat. Masjid ini dahulunya dibangun oleh masyarakat Limau Sunde dengan sukarela dan dana sedanya. Luasnya sekitar $17 \times 12$ meter yang dimana bentuknya seperti Masjid Joglo. Pada awal mula perencanaan pembangunan masjid tersebut terdapat suatu masalah yang bermula dari seorang pemilik tanah yang ingin mewaqafkan tanahnya untuk pembangunan masjid, namun ada satu orang warga lain yang ingin masjid tersebut dibangun di atas tanahnya pula. Sehingga akhirnya diputuskan bahwa masjid akan dibangun di atas kedua tanah mereka yang memang letaknya bersebelahan.

Masjid ini awalnya dibangun dengan dana sukarela dari masyarakat kampung dan hanya dibangun sederhana dengan material kayu. Karena struktur bangunannya yang terbuat dari kayu, lama kelamaan bangunan masjid mulai rusak karena terkena air dari banjir. Renovasi pertama dilakukan pada tahun 1972 dan tidak banyak perombakan yang dilakukan pada masjid tersebut. Pada tahun 1987 Masjid Jami' di bongkar habis dan dilakukan pembangunan ulang, di mana Gubernur Sumatera Utara pada saat itu memberikan bantuan dana sekitar 5 juta rupiah dan terdapat sumbangan pula dari Bambang Triatmodjo dan istrinya Halimah serta ayahnya yaitu Abdulah 
Kamil. Renovasi ini dilakukan sekitar 3 minggu lamanya. Pada minggu keempat tepatnya sebelum hari raya Idul Fitri, Masjid Jami' sudah selesai direnovasi. Kemudian pada tahun 1991 barulah dibangun menara dari Masjid Jami tersebut. Salah satu yang menjadi ciri khas dari Masjid Jami' ini ialah bentuk mimbarnya yang berada di tengah lantai dan menyatu dengan tanah atau lantai. Sejak awal hingga renovasi yang terakhir, mimbar ini tidak pernah dirubah bentuknya atau posisinya, hanya saja diperbaiki materialnya agar lebih kokoh.

\section{Makam}

Komplek makam tua terdapat di beberapa tempat di Kota Binjai. Keberadaan makam tua ini semakin memperkuat keberadaan Islam di Kota Binjai sejak abad ke- 18. Kebanyakan makam tua yang ditemukan dan masih ada hingga sekarang merupakan makam-makam orang besar, seperti makam Sultan, Syekh, Datuk Muda, OK (Orang Kaya), yang dahulu pernah berperan dalam perkembangan agama Islam di Kota Binjai. Terdapat makam tua di Kota Binjai yang merupakan makam dari Syeikh Muhammad Isa yaitu tahun 1870. Namun berbeda dari kebanyakan wilayah lain yang merupakan hasil pemecahan dari suatu kesultanan, di Kota Binjai sangat sedikit terdapat makam para bangsawan melayu yang dulunya pernah berkuasa di Binjai yang saat itu di bawah Kesultanan Langkat. Hampir semuanya dimakamkan di daerah Langkat. Dan terdapat beberapa makam tua lain di pemakaman Limau Sunde, namun kebanyakan rusak dan tidak diperbaiki lagi. Ada beberapa makam tua yang ditemukan di wilayah Kota Binjai antara lain: Makam K.H. Abdul Qarim merupakan salah satu ulama terkemuka di Kota Binjai. Beliau sempat menjabat sebagai kepala madrasah Jamiyatul Khairiyah. Dulunya madrasah ini dipimpin al-ustad H. Muhammad Nur Al-Faqih, namun setelah pembangunan madrasah yang baru di sebelah Masjid Raya Binjai saat ini Madrasah Jamiyatul Khairiyah dipimpin oleh K.H. Abdul Qarim. Dalam membina dan mengasuh madrasah ini beliau dibantu oleh Almarhum K.H. Abdul Halim Hasan. K.H. Abdul Qarim memimpin dan mengasuh madrasah hanya sampai tahun 1927. Hal ini disebabkan karena beliau diangkat dan ditugaskan sebagai mufti menggantikan Al-Ustad Muhammad Nur Al-Faqih.

Salah satu bukti sejarah yang ditinggalkan oleh Almarhum K.H. Abdul Qarim ialah Masjid K.H. Abdul Qarim yang berada di Keluruhan Rambung. Pengaruh yang diberikan Almarhum K.H. Abdul Qarim terhadap masyarakat di Kota Binjai sangat besar, sehingga nama beliau diabadikan menjadi salah satu nama di Kota Binjai. Beliau dimakamkan pada tahun 1870 di pekarangan masjid.

Abdul Halim Hasan lahir di Binjai pada tanggal 15 Mei 1901. Abdul Halim Hasan beraktivitas dalam dunia kelimuan Islam. Beliau mengajar di Universitas Islam Sumatera Utara. Pribadi seorang guru yang dimiliki oleh Abdul Halim Hasan mencerminkan seorang guru yang ideal yang sederhana. Kesederhanaan beliau dapat dirasakan oleh orang-orang yang bergaul dengan beliau, baik dari kalangan mahasiswa, tokoh akademis maupun 
masyarakat pada umumnya. Kesederhanaan itu tidak hanya terlihat dalam penampilan beliau tapi juga dalam bertutur dan mengekspresikan ide-ide beliau baik dalam tulisan, perkuliahan ataupun dalam aktifitas lainnya. K.H. Abdul Qarim memimpin dan mengasuh madrasah hanya sampai tahun 1927. Hal ini disebabkan karena beliau diangkat dan ditugaskan sebagai mufti menggantikan Ustadz Muhammad Nur Al Faqih.

\section{Yayasan-yayasan Pendidikan Islam di Kota Binjai}

Yayasan pendidikan di Kota Binjai tidak dapat dipungkiri merupakan lembaga yang signifikan dalam pengembangan Islam, oleh karena itu perlu untuk menginventarisasi yayasan yang ada antara lain: Yayasan Al-Ishlahiyah Binjai yang merupakan salah satu yayasan pendidikan Islam yang tertua di Kota Binjai. Yayasan Al-Ishlahiyah di Kota Binjai yang bergerak di bidang pendidikan agama Islam mulai tingkat Ibtidaiyah, Tsanawiyah, Aliyah sampai tingkat Perguruan Tinggi sehingga jumlah alumninya banyak. Melihat kiprah dan peran madrasah ini sejak berdiri pada tahun 1922 hingga sekarang dalam upaya turut mencerdaskan kehidupan bangsa yang berakhlak, bermoral, dan bertakwa kepada Allah Yang Maha Kuasa, bahkan lebih dari itu telah berhasil melahirkan ulama-ulama level nasional dan pejuang-pejuang kemerdekaan pada masa dahulu. Madrasah ini telah banyak berjasa bukan saja dalam menghasilkan ulama-ulama yang terkemuka tapi juga menjadi sarana pengkaderan pejuang-pejuang tangguh dalam merebut dan mempertahankan kemerdekaan Republik Indonesia. Tercatat sejumlah nama pejuang yang telah diabadikan pada "batu bertengger" yang terletak di depan Madrasah yang diresmikan oleh Walikota Binjai Bapak Alm. H. Abadi Barus pada tanggal 10 November 1996 yang lalu.

Salah satu ulama terkemuka yang telah banyak menyisihkan waktunya untuk mengasuh Madrasah ini dan sekaligus menjadi Mudir (Kepala Sekolah) sejak tahun 1927 sampai masa penyerahan kedaulatan adalah Alm. K.H. Abdul Halim Hasan. Dan ulama-ulama besar lainya yang telah menghidupkan madrasah ini seperti Alm. KH. A. Qarim, Alm. Ustadz H. Zainal Ariffin Abbas, Alm. Ustadz Abdul Rahim Haitami, dan Alm. Ustadz Bustami Ibrahim.

Pada periode pertama (22 November 1922), Madrasah Al-Ishlahiyah berdiri sejak tahun 1922 tepatnya 22 November 1922. Pada awal berdirinya madrasah ini bernama Madrasah "Jam'iyatul Khairiyah" sesuaikan dengan nama perkumpulan yang mendirikannya yaitu Jam'iyatul Khairiyah perkumpulan ini terdiri saudagar-saudagar Islam yang ada di Binjai terutama mereka yang bertoko di kedai panjang (sebutan rumah toko di kota Binjai sekarang).

Pada periode kedua (1930), seiring dengan tuntutan dari perjuangan dan untuk menyesuaikan diri dengan situasi perkembangan zaman pada masa itu, Alm. K.H. Abd. Halim Hasan mengganti nama Madrasah Jami'yatul Khairiyah menjadi "Arabiyah School". Hal ini dimaksudkan agar madrasah ini tidak hanya sekadar lembaga pendidikan agama yang kaku tetapi mampu mengikuti 
perkembangan zaman. Pada periode ketiga (1950), Perguruan Al-Ishlahiyah mengembangkan perguruannya mulai dari taman kanak-kanak hingga perguruan tinggi. Pada tahun 1989 oleh pengurus Yayasan Al-Ishlahiyah telah membuka secara resmi Institut Agama Islam Al-Ishlahiyah (IAIA) yang terdiri dari dua fakultas yaitu: Fakultas Tarbiyah dan Fakultas Dakwah.

Al-Jam'iyatul Washliyah berdiri di Binjai tahun 1938, organisasi ini mulai menunjukan perkembangannya di berbagai bidang. Perkembangan tersebut ditujukan untuk mewujudkan Al-Jam'iyatul Washliyah sebagai suatu organisasi yang eksis dalam kehidupan masyarakat dan bernegara yang memiliki peran besar pada waktu itu. Hal tersebut juga dilaksanakan untuk mencapai tujuan-tujuan Al-Jam'iyatul Washliyah sebagai suatu organisasi kemasyarakatan yang berhaluan Islam. Al-Jam'iyatul Washliyah bertujuan menegakkan ajaran Islam untuk terciptanya masyarakat yang beriman, bertaqwa, cerdas, amanah, adil, makmur, dan diridhai Allah SWT. Sejak tahun 1940 di Binjai, mulai dibangun lembaga pendidikan atau perguruan. Di kota Binjai Al-Jam'iyatul Washliyah telah mempunyai perguruan mulai dari Tadjhizi, Ibtida'i, Tsanawiyah.

Al-Jam'iyatul Washliyah di Binjai ini dibawa oleh orang-orang Mandailing. Awalnya mereka itu bertujuan untuk membentuk suatu pengajian untuk belajar agama Islam. Gedung awal yang digunakan untuk pengajian ini berbentuk seperti rumah panggung, dahulunya terletak tepat berada di depan madrasah Al-Jam'iyatul Washliyah yang berada di Binjai kota. Mereka juga membuat perkumpulan-perkumpulan untuk belajar mengaji di mushollamusholla sekitarnya. Kemudian mereka jugalah yang merupakan pengurus AlJam'iyatul Washliyah dengan mendirikan madrasah dan lembaga formal untuk anak-anak usia belajar di Binjai pada tahun 1940.

\section{Ulama di Kota Binjai}

Ada beberapa tokoh yang ikut mengembangkan agama Islam di Kota Binjai. Salah satunya yaitu Syeikh Abdul Halim Hasan. Syeikh Abdul Halim Hasan lahir di Binjai pada tanggal 15 Mei 1901. Orang tuanya bernama H. Hasan, seorang petani. Masa kecil Abdul Halim Hasan Binjai mencerminkan seorang anak yang haus akan ilmu-ilmu Islam. Banyak hal yang membuktikan bahwa beliau adalah seorang yang rajin dalam menuntut ilmu. Pada masa selanjutnya, Abdul Halim Hasan beraktivitas dalam dunia keilmuan Islam. Beliau mengajar di Universitas Islam Sumatera Utara. Pribadi seorang guru yang dimiliki oleh Abdul Halim Hasan mencerminkan seorang guru yang ideal yang sederhana. Kesederhanaan beliau dapat dirasakan oleh orang-orang yang bergaul dengan beliau, baik dari kalangan mahasiswa, tokoh akademis maupun masyarakat pada umumnya. Kesederhaan itu tidak hanya terlihat dalam penampilan beliau tapi juga dalam bertutur dan mengekspresikan ide-ide beliau baik dalam tulisan, perkuliahan ataupun dalam aktivitas lainnya.

Istimewanya adalah bahwa kesederhanaan tersebut ternyata disertai dengan wawasan dan pengetahuan yang luas dalam bidang keilmuan yang 
beliau dalami. Semua orang yang bergaul dengan beliau mengakui bahwa Abdul Halim Hasan adalah seorang yang luas dan dalam pengetahuannya. Kedalaman ilmu dan luasnya wawasan yang beliau memiliki kemudian membentuk seorang ulama yang terkenal dengan pemikiran yang moderat. Kemoderatan tokoh ini sebagai seorang dosen diakui oleh mahasiswanya, begitu juga dalam ruang lingkup yang lebih luas, moderatisme yang merupakan salah satu keistimewaan Abdul Halim Hasan Binjai akan terlihat dalam pemikirannya, seperti yang terlihat dalam tulisan-tulisan beliau, termasuk pada Tafsir Ahkam. Salah satu bentuk moderatisme pemikiran beliau adalah sikapnya yang tidak pernah mematok yang mana yang benar dalam pemikiran. Hal ini memang akan terlihat pada diri seorang tokoh yang memahami betul bagaimana sebuah pemikiran muncul dan berbeda dengan yang lainnya.

Sejak tahun 1920 Abdul Halim Hasan telah mulai mengajar di Binjai hingga tahun 1947. Beliau memberikan pelajaran-pelajaran agama dengan bijaksana di mana dalam pelaksanaan pengajarannya semua pokok-pokok masalah yang muncul diuraikan secara terbuka dan terus terang, serta mengambil keputusan secara adil tanpa terpengaruh oleh suatu golongan tertent. Beliau memegang beberapa tugas dan jabatan selama hidupnya, di antaranya menjadi ketua Umu Al-Hilal (Organisasi Pemuda) Kampung Limau Sundai, anggota Majelis Syar'i 1937 di Binjai, Ketua Umum Majelis Islam Tinggi (MIT) tahun 1943 di Binjai, Kepala Jawatan Agama Kabupaten Langkat/Binjai sampai pensiun, Guru besar UISU Medan dan masih banyak lagi. Pada hari Jum'at 14 November 1969 beliau mengalami sakit dan sempat dirawat di Rumah Sakit PNP II Bangkatan Binjai untuk dirawat.

Kemudian pada tanggal 15 November 1969 Abdul Halim Hasan wafat dalam usia 68 tahun 6 bulan. Beliau dimakamkan di pemakaman tanah waqaf Kampung Limau Sundai Binjai. K.H. Abdul Qarim merupakan salah satu ulama terkemuka di Kota Binjai, beliau sempat menjabat sebagai kepala madrasah Jamiyatul Khairiyah dulunya madrasah ini dipimpin al-ustad $\mathrm{H}$. Muhammad Nur Al-Faqih namun setelah pembangunan madrasah yang baru di sebelah Masjid Raya Binjai saat ini Madrasah Jam'iyatul Khairiyah dipimpin oleh K.H. Abdul Qarim. Dalam membina dan mengasuh madrasah ini beliau dibantu oleh K.H. Abdul Halim Hasan. K.H. Abdul Qarim memimpin dan mengasuh madrasah hanya sampai tahun 1927. Hal ini disebabkan karena beliau diangkat dan ditugaskan sebagai mufti menggantikan Ustadz Muhammad Nur Al Faqih.

Salah satu bukti sejarah yang ditinggalkan oleh K.H. Abdul Qarim ialah Masjid K.H. Qarim yang berada di keluruhan Rambung Dalam, Kecamatan Binjai Selatan. Pengaruh yang diberikan Almarhum K.H. Abdul Qarim terhadap masyarakat di Kota Binjai sangat besar, sehingga nama beliau diabadikan menjadi salah satu nama di Kota Binjai. Beliau dimakamkan pada 1870 di kecamatan Rambung Barat, Binjai Selatan dan letaknya di pekarangan Masjid K.H. Qarim. Haji Zainal Ariffin Abbas, beliau adalah pengarang buku- 
buku agama termasuk dalam jumlah yang banyak. Di antara karangannya "Peri Hidup Rasulullah S.A.W", yang merupakan sirah Nabi Muhammad S.A.W. yang paling lengkap dan ilmiah dalam bahasa Indonesia. Beliau ialah seorang pengajar, penulis, pendakwah, ilmuwan, pedagang, petani, industriawan, birokrat, bahkan politisi dan negarawan. Haji Zainal Arifin Abbas pernah mengajar di Arabiyah School Binjai untuk mengajar agama dan ilmiah. Haji Zainal Ariffin Abbas bersama dengan Ustadz Haji Abdul Halim Hasan dan Haji Abdul Rahim Haitami pernah mengarang bersama dan menghasilkan terjemahan dan Tafsir Al-Qur'an pada tahun $1355 \mathrm{H} / 1936 \mathrm{M}$. Mereka diberi gelar tiga serangkai dalam penyusunan Tafsir Al-Qur'an oleh Pangeran Langkat Hulu di Binjai Tengku Amir Hamzah.

\section{PENUTUP}

Islam menjadi mayoritas di Kota Binjai yang disebabkan oleh keberadaan Kesultanan Asahan dan daerah atau wilayahnya yang bermayoritas suku Melayu. Persebaran agama yang mengalami perkembangan pesat hingga kini menjadikan agama-agama lain seperti Kristen, Hindu, Buddha juga mengalami perkembangan akibat mobilitas penduduk dari waktu ke waktu.

Masuk dan berkembangnya agama Islam tidak terlepas dari pengaruh Kesultanan Langkat. Islam masuk ke Kota Binjai melalui dua cara, yang pertama karena perluasan daerah yang dilakukan oleh Kesultanan Langkat dan yang kedua dibawa oleh para pedagang dari negara tetangga yang mengadakan transaksi dagang di antara muara Sungai Bingai dan aliran Sungai Wampu. Letaknya yang strategis menjadikan Binjai berkembang pesat dan mengalami banyak perkembangan di beberapa bidang seperti perkebunan dan infrastruktur. Hal ini mengakibatkan munculnya pemukiman-pemukiman baru yang berkembang di Binjai dan menjadikan perkembangan Islam meluas di Binjai.

Bukti bahwa Islam di kota Binjai sudah lama menapak dapat dilihat dari perspektif sejarah dengan banyaknya peninggalan yang terpelihara secara baik dan dapat dilihat sampai sekarang di antaranya masjid, makam, kampung, madrasah atau sekolah, dan ulama-ulama. Mesekipun Kota Binjai mengalami perkembangan zaman, namun masih terdapat beberapa peninggalan sejarah Islam yang masih bisa dilihat keberadaannya.

\section{REFERENSI}

Aceh, Aboebakar. (1985). Sekitar Masuknya Islam ke Indonesia. Solo: Ramadhani. Azra, Azyumardi. (1998). Jaringan Ulama. Bandung: Mizan.

Koentjaraningrat. (2009). Pengantar Ilmu Antropologi. Jakarta: PT. Rineka Cipta. Kuntowijoyo. (2003). Metodologi Sejarah. Yogyakarta: PT. Tiara Wacana. Kuntowijoyo. (2006). Budaya dan Masyarakatnya.Yogyakarta: Tiara Wacana. Loeb, Edwin. (2013). Sumatra: Sejarah dan Masyarakatnya. Yogyakarta: Penerbit Ombak. 
Pane, Imam Mahdi. (2010). Nilai Historis tentang Peninggalan Historis sebagai Cagar Budaya di Kota Binjai. Skripsi tidak diterbitkan. Medan: Universitas Negeri Medan.

Pulungan, Abbas. (2008). Perkembangan Islam di Mandailing. Bandung: Citapustaka Media Perintis.

Reid, Anthony. (2011). Menuju Sejarah Sumatera: Antara Indonesia dan Dunia. Jakarta: Yayasan Obor Indonesia.

Renier, G.J. (1997). Metode dan Manfaat Ilmu Sejarah. Yogyakarta: Pustaka Pelajar. Saifullah. (2010). Sejarah dan Kebudayaan Islam di Asia Tenggara. Yogyakarya: Pustaka Pelajar.

Siregar, Nur Hikmah. (2013). Eksistensi Al-Jam'iyatul Washliyah dalam Bidang Pendidikan di Kecamatan Binjai Kota di Kota Binjai Tahun 1940-2012. Medan: Universitas Negeri Medan.

Syam, Nur. (2005). Islam Pesisir. Yogyakarta: LKiS Yogyakarta.

Yatim, Badri. (2008). Sejarah Peradaban Islam. Jakarta: PT. RajaGrafindo Persada. 